\title{
Review \\ Three-Dimensional Airway Spheroids and Organoids for Cystic Fibrosis Research
}

\author{
Onofrio Laselva (D) and Massimo Conese *(D) \\ Department of Medical and Surgical Science, University of Foggia, 71122 Foggia, Italy; onofrio.laselva@unifg.it \\ * Correspondence: massimo.conese@unifg.it; Tel.: +39-0881-588019; Fax: +39-0881-588047
}

check for

updates

Citation: Laselva, O.; Conese, M. Three-Dimensional Airway Spheroids and Organoids for Cystic Fibrosis Research. J. Respir. 2021, 1, 229-247. https://doi.org/10.3390/jor1040022

Academic Editor: Cesar A. Moran

Received: 31 August 2021

Accepted: 28 September 2021

Published: 7 October 2021

Publisher's Note: MDPI stays neutral with regard to jurisdictional claims in published maps and institutional affiliations.

Copyright: (c) 2021 by the authors. Licensee MDPI, Basel, Switzerland. This article is an open access article distributed under the terms and conditions of the Creative Commons Attribution (CC BY) license (https:/ / creativecommons.org/licenses/by/ $4.0 /)$.

\begin{abstract}
Cystic fibrosis (CF) is an autosomal recessive multi-organ disease caused by mutations in the CF Transmembrane Conductance Regulator (CFTR) gene, with morbidity and mortality primacy related to the lung disease. The CFTR protein, a chloride/bicarbonate channel, is expressed at the apical side of airway epithelial cells and is mainly involved in appropriate ion and fluid transport across the epithelium. Although many animal and cellular models have been developed to study the pathophysiological consequences of the lack/dysfunction of CFTR, only the three-dimensional (3D) structures termed "spheroids" and "organoids" can enable the reconstruction of airway mucosa to model organ development, disease pathophysiology, and drug screening. Airway spheroids and organoids can be derived from different sources, including adult lungs and induced pluripotent stem cells (iPSCs), each with its advantages and limits. Here, we review the major features of airway spheroids and organoids, anticipating that their potential in the CF field has not been fully shown. Further work is mandatory to understand whether they can accomplish better outcomes than other culture conditions of airway epithelial cells for CF personalized therapies and tissue engineering aims.
\end{abstract}

Keywords: cystic fibrosis; cystic fibrosis transmembrane conductance regulator; drug screening; human nasal cells; human bronchial cells; induced pluripotent stem cells; model disease; CFTR modulators

\section{Introduction}

Cystic fibrosis (CF) is an autosomal recessive disease caused by mutations in the $C F$ Transmembrane Conductance Regulator (CFTR) gene, mapped on the long arm of chromosome 7. Despite CF is a multi-organ syndrome, the chief cause of morbidity and mortality of $\mathrm{CF}$ patients is the lung disease occurring at variable ages, but whose onset is typical of infancy [1].

Over 2000 CFTR variants have been discovered in the CFTR gene and listed in the CFTR1 (http:/ / www.genet.sickkids.on.ca, accessed on 31 August 2021) and the CFTR2 (https:/ / cftr2.org/, accessed on 31 August 2021) databases, including about 322 of the most common variants with pathogenic consequences. CFTR2 uses information from the 88,000 patients with specific CF variants from the United States, Canada, and Europe. The classification of CFTR variants has been purported to comprise phenotypic severity, variant type, and the effect on the CFTR protein. CFTR mutations can be classified into six classes based on their phenotypic consequences. Class I mutations may lead to premature stop codons, causing a lack of protein synthesis (i.e., G542X, W1282X). Class II mutations cause defective protein processing, which causes improper folding of CFTR during protein synthesis and leading to ER-mediated degradation through the proteasome (i.e., F508del, N1303K). Other mutations allow CFTR to be expressed at the apical membrane but remain non-functional due to problems in anion channel gating or apical stability. In particular, Class III mutations cause defective channel regulation (i.e., G551D, S549N); Class IV mutations determine defective channel conduction (i.e., $R 117 H, R 334 W$ ); Class V mutations are responsible for reduced protein synthesis (i.e., $A 455 E, 3849+10 \mathrm{kbC} \rightarrow \mathrm{T}$ ); 
Class VI mutations cause reduced protein stability, which includes rescued-F508del-CFTR or Q1411X [2,3]. To take into account all splicing mutations already present in class $\mathrm{V}$ and their rescuability by CFTR modulators, De Boeck and Amaral proposed identifying a novel Class VII, which includes unrescuable mutations [4]. More recently, the molecular phenotypic complexity of CF mutants has led to the proposal to expand the six mutant categories to better reflect the complicated mutant phenotypes [5].

The airway epithelium is constituted of multiple cell types, including basal cells (BCs), club/secretory cells (SCs), goblet cells (GCs), and multi-ciliated cells (MCCs), as well as of less frequent cell types, including ionocytes, neuroendocrine, tuft, and intermediate progenitor cells, such as deuterosomal cells [6]. The CFTR protein is expressed by airway BCs, MCCs, SCs, and ionocytes at variable levels [7-9]. Lung disease derives from the dehydration of mucus secretions and the annihilation of mucociliary transport, thereby favoring infection and subsequent chronic inflammatory response [10]. The diminished chloride and bicarbonate secretion into the airway lumen, exerted by the CFTR protein, is responsible for sticky mucus accumulating [11]. Moreover, the hyperactivation of the epithelial sodium channel $(\mathrm{ENaC})$ leads to heightened sodium and fluid absorption [12], contributing to the loss of the mucociliary escalator. Adding to this, with the lack of CFTRdependent bicarbonate secretion, airway surface liquid $\mathrm{pH}$ falls and impairs antibacterial activity [11]. The specific role of the different cell types in ion and fluid homeostasis and pathology of the CF airway disease has not been exactly defined yet.

\subsection{Novel Therapies for $C F$}

Therapies for the CF lung disease encompass symptomatic treatments, such as antibiotics for infections, physiotherapy for removing sputum from the airways, and mucolytics to make sputum less viscous and sticky and allow it to be expectorated [13]. Nowadays, etiologic therapies have been included in the clinical treatment armamentarium, i.e., those directly modulating the various defects presented by the mutated CFTR protein called CFTR correctors and potentiators [14]. CFTR correctors are pharmacological compounds that rescue the mutated CFTR to the cell surface. Lumacaftor (or VX-809) has been shown to rescue F508del-CFTR function to approximately 15\% of normal channel activity in human bronchial epithelial cells treated in combination with the potentiator Ivacaftor (VX-770) [15]. The Lumacaftor-Ivacaftor combination has been approved by the US Food and Drug Administration (FDA) as Orkambi for patients bearing the F508del mutation in homozygosity. More recently, the related Tezacaftor (or VX-661)-Ivacaftor combination has been approved as Symdeko/Symveki (US/Europe) [16,17]. However, Orkambi and Symdeko/Symveki therapies are associated with modest clinical responsiveness for patients homozygous for F508del [16]. Therefore, recently, the FDA approved as Trikafta/Kaftrio (US/Europe), the triple combination of two correctors, Elexacaftor (VX-445) and Tezacaftor, together with the potentiator Ivacaftor for patients bearing the F508del mutation at least on one allele [18]. Moreover, it has been demonstrated that Trikafta/Kaftrio was also effective on rarer class II mutations [19-21]. Based on in vitro cell-based studies, the FDA extended the list of CFTR mutations for which Trikafta/Kaftrio treatment could be clinically beneficial [22].

While approximately $90 \%$ of CF patients, who retain at least partial expression of full-length CFTR protein, should benefit from these CFTR modulators [18,23-27], CF patients bearing large deletions, splicing, and nonsense mutations, as well as those who are non-responders, do not have approved therapies at their disposal. As mentioned above, Class I mutations generate a premature termination codon (PTC) in the CFTR mRNA; therefore, they are degraded by nonsense-mediated mRNA decay (NMD) [28]. One possible approach for PTC mutations is to use read-through compounds (such as gentamycin, G418 and ELX-02 [29-31]), which promote the insertion of an amino acid at the position of the nonsense codon and allow full-length protein synthesis. Moreover, it has been demonstrated that the inhibition of NMD by small molecules (SMG1i or NMDI-14) or antisense oligonucleotides (ASOs), in combination with G418 and/or CFTR modulators, rescued W1282X-CFTR function in the 16HBE cell line and primary nasal 
epithelial cells [30,32-34]. Moreover, gene and stem cell-based therapy or genome editing by CRISPR-Cas9 are being explored in in vitro studies as therapeutic approaches for CF patients bearing nonsense mutations [35-40].

\subsection{In Vivo and In Vitro Models for CF}

The use of appropriate models is particularly important to advance novel drug and gene therapies. Early modeling of $\mathrm{CF}$ in mice hindered investigations of airway disease pathogenesis, as well as the development and testing of potential therapeutics, while lung disease modelled by CF rats, ferrets, and pigs share several similarities to that observed in humans. Since one single animal model will not be sufficient to investigate all CF-related questions [41], relevance is increasingly recognized for ex vivo and in vitro cellular models obtained from human sources, including induced pluripotent stem cells (iPSCs), resident stem cells from the intestine and lung, and primary airway epithelial cells (AECs) [42].

A number of cell lines are being used to test the efficacy of CFTR modulator cocktails or gene therapies in rescuing the functional expression of F508del-CFTR. These models include Human Embryonic Kidney (HEK293), Fischer Rat Thyroid (FRT), and human bronchial epithelial cell lines (e.g., CFBE41o-) [21,43,44]. However, heterologous expression systems do not always predict CFTR modulators' efficacy in vitro $[45,46]$. These limitations might be overcome by using patient-derived tissues, including primary airway epithelial cells (AECs) and induced pluripotent stem cells (iPSCs).

Nowadays, these patient-derived cellular models include culture on permeable inserts that allow cell polarization and differentiation and three-dimensional (3D) organoid cultures [47]. Organoids can better mimic the complex environment of the respiratory mucosa, define the relationship among different cell types, allow assessment of CFTR function and permit high-throughput screening in drug- and gene therapy platforms. Although a steady advancement in CFTR modulator therapy, the efficacy and safety of the approved drug for $\mathrm{CF}$ patients bearing rare mutations have not been evaluated. CFTR theratyping, i.e., the use of CFTR modulators to define defects in CFTR in vitro with patient-derived and tissue-based models, has the potential to identify novel CFTR modulators that could restore rare CFTR variants $[48,49]$.

Culturing AECs at the air-liquid interface (ALI) allows obtaining a pseudostratified mucociliary differentiated epithelium, which was utilized to advance our knowledge about the cellular biology and physiology of cystic fibrosis, for instance, by the measurement of channel conductance using an Ussing chamber or patch clamping [50,51]. AECs ALI cultures from bronchi are currently the "gold standard" for preclinical testing of CFTR modulators [49]. However, primary AEC cultures do have inherent drawbacks: there is limited availability of specimens; they are likely damaged by the infection, need ill-defined, expensive media; and in the case of bronchial epithelial cells, they are highly invasive to obtain because lung transplant is required [42,52].

\subsection{Spheroids and Organoids for $C F$}

The term "organoid" has been used for describing 3D self-organized aggregates of multiple cell types derived from stem/progenitor cells. To form organoids, cells are grown within gels made of a complex mixture of different extracellular matrix (ECM) proteins, including laminin, fibronectin, collagen, and heparin sulfate proteoglycans $[53,54]$. Although not all organoids made up of epithelial cells have been formed within an ECM, such as matrigel, we refer herein to organoids as well [55]. However, the 3D cultures should be named organoids if they have demonstrated self-renewal capacity, whereas the term spheroid should be strictly for those structures for which self-renewal has not been achieved [56].

Spheroids and organoids have been generated to study human disease and test drug efficacy in the CF field since intestinal organoids were first used when obtained from adult stem cells present in rectal biopsies [57,58]. The forskolin-induced swelling (FIS) assay was instrumental in comprehending the development of mutation-specific correctors, 
deciding whether the therapeutic interventions can have an impact on individual clinical phenotype, and characterizing CFTR function of rare CFTR variants [59]. By studying functional CFTR repair by C1-C18 correctors (Cystic Fibrosis Foundation Therapeutics, Bedford, MA, USA) in primary intestinal CF organoids with different trafficking mutants, Dekkers and colleagues [60] observed the correction of CFTR-F508del and -A445E in 13 out of 19 compounds, while none of these compounds restored function of CFTR-N1303K, showing for the first time that the CFTR corrector efficacy selectively depends on the type of folding and trafficking defect. More recently, it has been reported that, in subjects with 28 different genotypes, residual CFTR function in rectal organoids strictly correlated with sweat chloride values, as demonstrated by the FIS assay. On the other hand, when studying the same genotypes, CFTR function rescue by CFTR modulators tightly correlated with the mean improvement in lung function and sweat chloride from published clinical trials. Importantly, based on the organoid results, two subjects with rare mutations (Q359K_T360K and $E 60 \mathrm{~K}$ ) started modulator treatment, resulting in a major clinical benefit [61]. Overall, these results position intestinal organoids as in vitro potential models to guide precision medicine in patients with $\mathrm{CF}$, even those with rare mutations. Moreover, recently, no correlation was observed between the Lumacaftor-Ivacaftor-induced FIS in organoids versus the in vivo improvement of CFTR function determined by sweat chloride concentration, nasal potential difference, or intestinal current measurement in 21 patients homozygous for F508del [62], suggesting that future studies in a larger group of patients with a spectrum of responsive CFTR mutations and more effective CFTR modulators are needed. Intestinal organoids can expand over long time periods and be biobanked [58,63]; however, ion and fluid transport in the gut differs from that in the airways, challenging the usefulness and predictivity of intestinal organoids in drug discovery and optimization for the CF airway disease. Indeed, $\mathrm{ENaC}$ currents are not detectable in intestinal organoids [63]; thereby, a crucial pathophysiological interaction between CFTR and ENaC that occurs in the epithelium of conducting airways is missing. It has been recently shown that the measurement of CFTR and ENaC activity was possible in opened iPSC-derived intestinal organoids-a configuration that is adaptable to medium-high throughput, high-content phenotypic analyses [64].

In this review, we shall describe the different spheroid and organoid types which have been constructed from various sources of airway epithelial cells, i.e., iPSCs and AECs, with particular reference to works that have investigated the CFTR activity and its modulation by etiological therapies. Since the CF lung disease stems from bronchi/bronchioli, airway organoids recreating distal airways, i.e., so-called alveolospheres $[65,66]$, will not be discussed here.

\section{Airway Spheroids from Primary Airway Epithelial Cells}

Airway spheroids can be obtained as self-organizing aggregates of terminally differentiated cells [67], and they can last for up to 12 weeks [68] (Figure 1a). Alternatively, they can be derived from primary basal cells embedded in matrigel [69] or primary AECs cultured in media containing morphogenic cues for self-renewal [70] (Figure 1b). In this section, we will give an overview of the 3D spheroid methods depicted in Figure 1a (spheroids formed in ECM-free conditions) and Figure 1b (spheroids formed in an ECM matrix). 


\section{a. Nasospheroids in media}

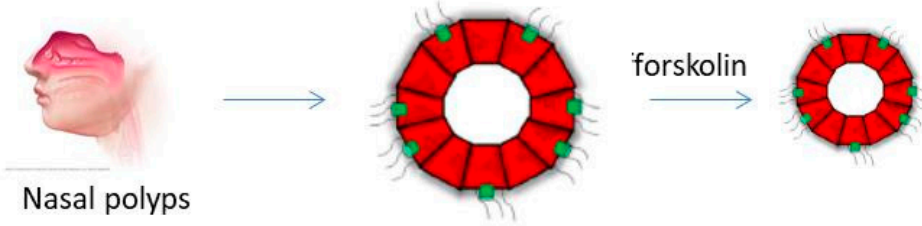

\section{b. Nasospheroids/Bronchospheroids in matrigel}

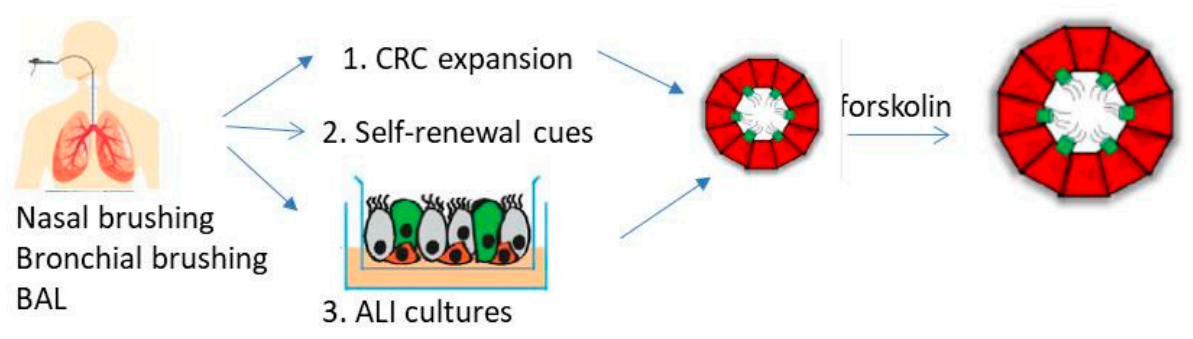

\section{c. iPSC-derived organoids in matrigel}

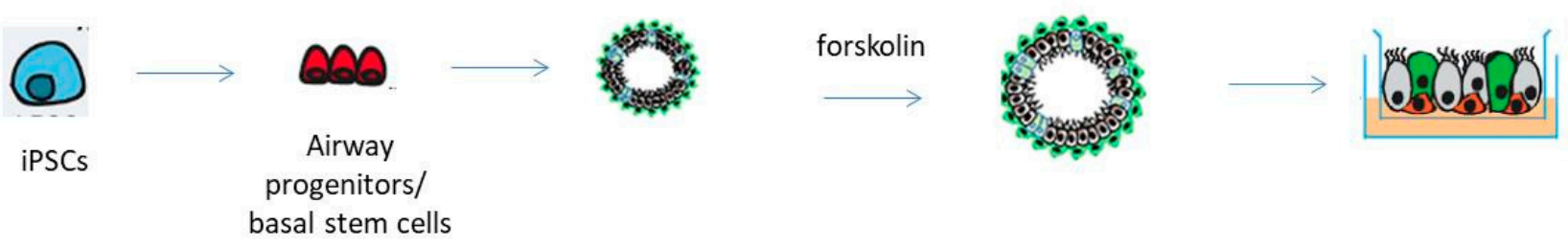

Figure 1. Overview of available strategies to generate airway spheroids/organoids. (a) Spheroids can be obtained from nasal polyps upon enzymatic digestion or cells derived from nasal curettage/brushing and cultured in liquid media, not allowing their adherence to the plate (e.g., by gentle shaking). (b) Differentiated or stem/progenitor cells obtained from nasal or bronchial brushing as well as from bronchoalveolar lavage (BAL) can be induced to form spheroids in matrigel. Three methods have refined the generation of such spheroids: (1) the conditioned reprogramming culture (CRC); (2) by adding self-renewal cues; (3) first forming 2D ALI cultures and then spheroids from them. (c) iPSC-derived lung progenitor cells or basal stem cells are directed to form organoids in matrigel. Organoids can eventually be "split-open" on 96-well plates. Spheroids/organoids can be studied by forskolin-mediated CFTR activation and subsequent fluid transport, with shrinking (a) or swelling $(\mathbf{b}, \mathbf{c})$ depending on epithelial lumen formation.

Transplant-derived patient bronchial epithelial cultures (commonly referred to as HBE) have been used to study CFTR channel activity on the apical surface and the in vitro responses to CFTR modulators. Outcomes from these assays can be then translated to patient drug responses in the clinic [18,24]. The availability of these transplant-derived tissues is limited, and more accessible CF patient-specific tissue models for preclinical drug testing are being developed, such as the use of using nasal epithelial brushings to harvest nasal epithelial cells (NECs) for culturing [34,44,71-74]. Patient-derived nasal epithelial cultures show promise as a surrogate for bronchial or tracheal cultures with respect to CFTR function and functional rescue with modulators [75]. Moreover, despite primary cultures of nasal cells share many characteristics with bronchial cells (including limitations in passage numbers), NECs are more accessible, i.e., easier to collect by nasal brushing [76]. Pranke et al. showed that CFTR chloride channel responses observed in patient-derived nasal epithelial cultures correlated with individual's improvement in Forced Expiratory Volume in the 1st second $\left(\mathrm{FEV}_{1}\right)$, i.e., the gold standard outcome to measure drug efficacy, measured after the treatment with a combination of Ivacaftor and the CFTR corrector Lumacaftor (Orkambi) [71,77]. Moreover, Amaral's group demonstrated a correlation 
between CFTR rescue by CFTR modulators in primary nasal epithelial cells and rectal organoids from the same individual [78].

In general, primary HBE and NECs are able to efficiently divide only 3-4 population doublings [75,79]. First developed for obtaining long-term cultures of keratinocytes [80], the conditionally reprogrammed culture (CRC) technique was hereafter applied to HBE and NEC cultures. Basically, cells are cultured in the presence of an inhibitor of Rho-associated kinase (ROCK) onto a lethally irradiated mouse fibroblast feeder layer. This co-culture with animal-origin feeder cells will limit the application for human transplantation purposes. Therefore, CRC HBE monocultures are being developed (i.e., without a murine fibroblast feeder layer), which make use of more chemically-defined growth media (for a review, see [81]). Either as co-cultures or monocultures, CRC HBE and NEC culturing methods have been used in the realization of spheroid and organoids to take advantage of this increased proliferative efficiency. There are drawbacks concerning CRC cultures. One is represented by the potential contamination of CRC-expanded AECs with animal-origin feeder cells, which makes the co-culture CRC HAE method not suitable for human therapy [82]. On the other hand, CRC monoculture-expanded AECs display reduced beating frequency of airway cilia and lower ion currents than the ALI-differentiated AECs, which were expanded using the co-culture CRC method [83]. Other factors affecting primary CRC AEC culture success include the sampling method (induced sputum, tracheal aspirate, bronchoalveolar lavage, nasal brushing), age group, donor lifestyle (e.g., smoking), used medications, initial cell number, and subculturing methods. All these aspects should be considered before choosing the most appropriate CRC AEC cellular model for particular applications in airway research.

\subsection{Spheroids from Differentiated Nasal Epithelial Cells}

Spheroids formed from human NEC (Figure 1a,b) have been used for multiple purposes, including the study of ciliation, mucus production, and formation of cell-to-cell junctions [84-88]. By using these nasospheroids, others have been able to discriminate CF cultures from non-CF and have also demonstrated pharmacologic rescue of mutated CFTR using small molecules $[68,89,90]$. When NEC are cultured in liquid media not allowing their adherence to the plate, derived spheroids present a lumen-out configuration, while embedding NEC into basal membrane matrix such as matrigel allowed them to adopt a lumen-in configuration [91] (Figure 1a,b).

In the first of these works, Pedersen and colleagues studied free-floating spheroids from epithelial sheets that were obtained from nasal polyps upon enzymatic digestion [92-94]. Nasospheroids presented cilia on the outer apical aspect and a basolateral membrane pointing toward a fluid-filled lumen. These spheroids were used to characterize the ion transport and fluid absorption [92,93], highlighting that the basolateral side (inside) positive transepithelial potential difference (PD) during the influence of various agonists and ion channel blockers mimicked that of native tissue and conventional cultured airway epithelial cells. Amiloride, an $\mathrm{ENaC}$ inhibitor, reduced fluid absorption more in non-CF than in CF spheroids, a result explained by the lack of $\mathrm{Cl}^{-}$secretion in $\mathrm{CF}$ spheroids. A cAMP-induced increase in PD was seen in non-CF spheroids only. Fluid absorption rates of both CF and non-CF spheroids were not influenced by hyperosmotic stress, which, on the other hand, induced an increase in aquaporin- 5 expression at the apical spheroid membranes [94].

Others have subsequently reported similar nasospheroids derived from nasal brushing or curettage. They formed in 2-5 days from sheets of nonadherent nasal epithelial cells, and they could be maintained for at least 12 weeks in a serum-free medium [68]. These nasospheroids were highly differentiated, hollow spheres composed of a single layer of differentiated pseudostratified epithelial cells containing ciliated and nonciliated cell types, with cilia and CFTR expression facing the outside bath (Figure 1a). Upon CFTR activation by forskolin, non-CF spheroids shrank, an effect compatible with the efflux of chloride and water outside the spheroid, and this effect was counteracted by CFTRinh-172. The 
relevance of the CFTR activity in this assay was further demonstrated by the observation that $\mathrm{CF}$ nasospheroids showed no reduction in the cross-sectional area over time when CFTR was stimulated unless treated with modulators, i.e., the combination LumacaforIvacaftor. Interestingly, they noted response differences between F508del homozygote individuals and a substantial, albeit nonsignificant, reduction in size with Lumacaftor monotherapy in a rare mutation (I618T/F508del), indicating the usefulness of this assay in "n of 1 " studies.

In following studies, the CRC method was used to expand NEC (Figure 1b), so Brewington and colleagues formed nasospheroids from NEC, which were cultured and passaged onto an embryonic fibroblast feeder layer in the presence of the ROCK inhibitor Y27632 until NEC were transferred to matrigel for 7-10 days [89]. Microscopic analysis revealed the presence of a lumen and a slightly thickened spheroid wall, suggesting a pseudostratified epithelium. Nasospheroids were positive for markers of mature respiratory epithelia, including E-cadherin (adherens junctions), luminal $\mathrm{F}$ actin and alpha tubulin (indicating cilia), and the mucin MUC5AC (for mucus secretory cells). NEC spheroids from wildtype (wt) CFTR subjects swelled when stimulated with forskolin/IBMX with an average of $+16.0 \%$ from baseline. On the other hand, nasospheroids from F508del homozygotes generally shrank following acute stimulation with forskolin/IBMX and ivacaftor (mean $-7.0 \%$ ) but swelled following stimulation with Lumacaftor, with a mean increase of $+8.7 \%$ from baseline. Nasospheroids from heterozygotes for F508del and other mutations or homozygotes for other mutations swelled variably between control wtCFTR and F508del homozygous CFTR spheroids when stimulated with forskolin/IBMX $(+2.4 \%)$. Moreover, the response to CFTR modulators was variable and mutation-dependent. Interestingly, the nasosphere swelling response shows a tight correlation with same-subject ALI cultures with good epithelial electrophysiology, supporting the use of nasal spheroids as a model of basal and stimulated CFTR activity. Furthermore, NEC ALI culture was unsuccessful in several donors, highlighting the challenge of studying NECs under ALI and a potential benefit of NEC spheroid analysis. Interestingly, three of six subjects treated with CFTR modulators in vivo had clinical improvement in both FEV1 and body mass index (BMI), and all three had a corresponding $\geq 10 \%$ improvement in spheroid swelling, implying a relationship between the spheroid response to the drug and the in vivo clinical response. McCarthy et al. [95] further showed that nasal epithelial spheroids, which were obtained from a CF subject heterozygous for the rare mutation Ser1159Pro and F508del, were sensitive to Lumacaftor-Ivacaftor treatment, i.e., they swelled, and this behavior correlated with the pharmacological response of ALI monolayers. Importantly, a positive clinical response in terms of FEV1 and symptoms was recorded when this patient was treated with Lumacaftor-Ivacaftor.

To further make these nasospheroids amenable to medium-to-high throughput applications, Liu and colleagues implemented a CRC method culture to obtain millions of cells from small amounts of biopsy material. NEC organoids had the lumen on the interior, with evidence of cilia forming cells. Different differentiation markers were expressed, including MUC5AC and MUC5B, ZO-1, CFTR and FOXJ1 (for ionocytes), and CFTR co-localized with $\mathrm{ZO}-1$. The basal lumen ratio (BLR), i.e., the ratio of the mean luminal area to the total surface area, representing the luminal fluid present within organoids, allowed distinguishing organoids of different CFTR genotypes, i.e., non-CF, G551D/residual function (RF) mutation, F508del/G551D and F508del /F508del, with non-CF and F508del/F508del organoids showing higher and lower BLR, respectively. This parameter positively correlated with the baseline forskolin-stimulated short-circuit current in NEC cultures [90].

More recently, Beekman's group set up a novel approach in which evenly differentiated spheroids were established from ALI-differentiated NEC monolayers [96] (Figure 1b). Basically, fragments obtained from 2D cultures were embedded in matrigel leading to the formation of spheroids, scaling up to 48 wells of a 96-well plate from a single $12 \mathrm{~cm}^{2}$ transwell insert. The FIS assay showed that the CF spheroid did not swell and that a CFTRindependent fluid secretion in mediating spheroid swelling was present. This assumption 
was based on studies using $\mathrm{E}_{\mathrm{act}}$, which increased $\mathrm{Ca}^{2+}$ uptake via the transient receptor potential cation channel subfamily V member 4 (TRPV4) and determined swelling in only CF nasal spheroids, and TRVP4 inhibition, which suppressed FIS. Interestingly, $E_{a c t}$-induced swelling was significantly higher in CF spheroids compared to healthy controls, suggesting enhanced $\mathrm{Ca}^{2+}$-dependent CFTR-independent fluid secretion upon CFTR dysfunction. The optimization of culture conditions aimed to lessen CFTR-independent FIS and low CFTR expression by including neuregulin/IL- $1 \beta$, which improved the sensitivity to CFTR modulators (Ivacaftor/Lumacaftor) and allowed observing a consistent response to the triple combination of Ivacaftor-Tezacaftor-Elexacaftor.

\subsection{Spheroids from Airway Stem/Progenitor Cells}

Airway-resident stem cells with self-renewing and multi-differentiation capacities can be committed to generating spheroids which can be studied in the CF field [55]. Bronchial lung organoids may be generated from basal stem cells either obtained from lung explants, bronchial brushes, or commercially available normal or diseased primary human bronchial epithelial cell preparations, including of CF origin. Basal cell samples can be also obtained from the nasal passages by either brushing or curettage [97]. They are usually cultured in matrigel or basement membrane extracts to obtain a lumen-in configuration [69,98-101]. They could be useful to understand not only CFTR function and modulation but also the relevance of inflammatory and infection-related signals in the airway pathology associated with CF, for example, mucus metaplasia. Danahay and colleagues [99] derived so-called "bronchospheres" from the multipotent p63 + NGFR + ITGA6+ airway basal cell, which they used to demonstrate the relevance of both IL-13 and IL-17 in goblet cell metaplasia via a Notch2-dependent mechanism. Sprott et al. [101] identified flagellin, a Toll-like receptor (TLR) ligand, as a key driver of loss of cilia formation and mucus hyperproduction in bronchospheres.

Spheroids that were maintained for more than one year in culture were established from lower airway epithelial cells procured with lung biopsies or bronchoalveolar lavage fluid specimens [70]. Lung cells were embedded in basement membrane extracts containing signaling cues for self-renewal, such as R-spondin, Noggin, FGF-7, and FGF-10, as well as BMP and TGF- $\beta$ inhibitory factors (Figure $1 \mathrm{~b}$ ). These organoids presented a lumenin configuration and were composed of a pseudostratified epithelium containing basal (cytokeratin KRT5+), goblet (mucin MUC5AC+), club (secretoglobin SCGB1A1+), and multi-ciliated cells (acetylated $\alpha$-tubulin-positive) cells. In the FIS assay, these spheroids presented a CFTR-dependent swelling that was not completely abolished by the CFTRinh172. Interestingly, the swelling occurred upon incubation with $E_{\text {act, }}$, an activator of TMEM16A, a calcium-activated chloride channel. CF spheroids obtained from subjects with different mutations showed reduced swelling compared to wild-type spheroids recovered by Lumacaftor and Ivacaftor pre-incubation.

In general, airway spheroids need to be better characterized for their dynamic range, i.e., whether they show residual function upon forskolin stimulation and how they respond to CFTR modulators across genotypes, as it has been conducted with intestinal organoids [60,61]. Moreover, they should be evaluated for their predicted clinical response [61]. It would also be essential to implement biobank storage and high-throughput analysis to assay all the new CFTR modulators and gene therapy approaches that are being explored in the CF field. Moreover, there is a need for a "standardization protocol" to make the use of these models comparable and reproducible among different labs. This issue has been recently faced up with intestinal organoids. Three academic laboratories evaluated CFTR function by FIS the same six CF patients with distinct CFTR genotypes, ranging from severe Class I to Class V mutations [102]. In the case of airway organoids, variability is much higher since, for instance, there are different methods for CRC or even for growing spheroids in matrigel [91]. A face-to-face analysis of different methods should be carried out to have a unique protocol valid for all researchers and thereby optimize and consolidate results. 
Table 1 reports the main morphological and functional characteristics of airway spheroids derived from either differentiated or progenitor cells and their use in CF research.

Table 1. Airway spheroids obtained from airway epithelial cells.

\begin{tabular}{|c|c|c|c|c|}
\hline Study & Spheroid Model & $\begin{array}{c}\text { Morphology and } \\
\text { Antigen Expression }\end{array}$ & Function & $\begin{array}{c}\text { Pharmacological } \\
\text { Treatment }\end{array}$ \\
\hline $\begin{array}{l}\text { Pedersen et al., } \\
1999 \text { [92] }\end{array}$ & $\begin{array}{l}\text { CF }(n=9) \text { and non-CF } \\
\quad(n=17) \text { subjects. } \\
\text { Free-floating spheroids } \\
\text { from nasal } \\
\text { polyp-epithelial sheets. }\end{array}$ & $\begin{array}{l}\text { "Lumen-out" } \\
\text { configuration. The apical } \\
\text { ciliated membrane facing } \\
\text { the bath, and the } \\
\text { basolateral cell membrane } \\
\text { pointing toward a } \\
\text { fluid-filled lumen. }\end{array}$ & $\begin{array}{c}\text { Transepithelial PD } \\
\text { measurements compatible } \\
\text { with the presence of an } \\
\text { amiloride-sensitive } \mathrm{Na}^{+} \\
\text {absorption and } \\
\text { ATP-sensitive } \mathrm{Cl}^{-} \text {channel in } \\
\text { the apical membrane. } \\
\mathrm{CF} \text { spheroids PD was not } \\
\text { changed by the } \\
\text { increase in cAMP. }\end{array}$ & None. \\
\hline $\begin{array}{l}\text { Pedersen et al., } \\
1999 \text { [93] }\end{array}$ & $\begin{array}{l}\text { CF }(n=7) \text { and non-CF } \\
\quad(n=15) \text { subjects. } \\
\text { Free-floating spheroids } \\
\text { from nasal } \\
\text { polyp-epithelial sheets. }\end{array}$ & $\begin{array}{l}\text { "Lumen-out" } \\
\text { configuration. The apical } \\
\text { ciliated membrane facing } \\
\text { the bath, and the } \\
\text { basolateral cell membrane } \\
\text { pointing toward a } \\
\text { fluid-filled lumen. }\end{array}$ & $\begin{array}{l}\text { Fluid absorption rates were } \\
\text { equal in non-CF } \\
\text { and CF spheroids. } \\
\text { Amiloride inhibited fluid } \\
\text { absorption to a lower } \\
\text { residual level in non-CF than } \\
\text { in CF spheroids. }\end{array}$ & None. \\
\hline $\begin{array}{l}\text { Pedersen et al., } \\
2007 \text { [94] }\end{array}$ & $\begin{array}{c}\text { CF }(n=4) \text { and non-CF } \\
\quad(n=5) \text { subjects. }\end{array}$ & $\begin{array}{l}\text { "Lumen-out" } \\
\text { configuration. The apical } \\
\text { ciliated membrane facing } \\
\text { the bath, and the } \\
\text { basolateral cell membrane } \\
\text { pointing toward a } \\
\text { fluid-filled lumen. }\end{array}$ & $\begin{array}{l}\text { Hyperosmotic treatment } \\
\text { caused an increase in } \\
\text { epithelial water permeability } \\
\text { without changing fluid } \\
\text { absorption rates. }\end{array}$ & None. \\
\hline $\begin{array}{l}\text { Guimbellot } \\
\text { et al., } 2017 \text { [68] }\end{array}$ & $\begin{array}{c}\text { CF }(n=3) \text { and non-CF } \\
(n=9) \text { subjects. } \\
\text { CF genotypes: } \\
\text { F508del/F508del; } \\
\text { F508del/I618T; } \\
\text { G551D/F508del }\end{array}$ & $\begin{array}{l}\text { "Lumen-out" } \\
\text { configuration. The apical } \\
\text { ciliated membrane facing } \\
\text { the bath, and the } \\
\text { basolateral cell membrane } \\
\text { pointing toward a } \\
\text { fluid-filled lumen. } \\
\text { CFTR expression at the } \\
\text { level of apical region. }\end{array}$ & $\begin{array}{l}\text { Shrinking of non-CF } \\
\text { spheroids upon the increase } \\
\text { in cAMP levels. CF } \\
\text { spheroids showed } \\
\text { diminished volume } \\
\text { reduction following } \\
\text { CFTR activation. }\end{array}$ & $\begin{array}{l}\text { Lumacaftor- } \\
\text { Ivacaftor } \\
\text { treatment } \\
\text { partially restored } \\
\text { cross-sectional } \\
\text { area reduction of } \\
\text { CF nanospheroids. }\end{array}$ \\
\hline $\begin{array}{l}\text { Brewington } \\
\text { et al., } 2018 \text { [89] }\end{array}$ & $\begin{array}{c}\text { CF }(n=19) \text { and non-CF } \\
\quad(n=6) \text { subjects. } \\
\text { CF genotypes: } \\
\text { F508del/F508del }(n=9) ; \\
\text { others with at least one } \\
\text { non-F508del mutation }\end{array}$ & $\begin{array}{l}\text { "Lumen-in" configuration. } \\
\text { Cilia on the luminal } \\
\text { surface. Positive for } \\
\text { E-cadherin, luminal F actin } \\
\text { and alpha tubulin, and the } \\
\text { mucin MUC5AC. }\end{array}$ & $\begin{array}{l}\text { Non-CF spheroids swelled } \\
\text { upon CFTR stimulation. } \\
\text { NEC spheroids from F508del } \\
\text { homozygotes shrank } \\
\text { following CFTR stimulation. }\end{array}$ & $\begin{array}{c}\text { F508del } \\
\text { homozygous } \\
\text { spheroids swelled } \\
\text { when pre-treated } \\
\text { with Ivacaftor } \\
\text { and Lumacaftor, } \\
\text { or incubated at } \\
27^{\circ} \mathrm{C} \text {. }\end{array}$ \\
\hline $\begin{array}{l}\text { McCarthy et al., } \\
2018 \text { [95] }\end{array}$ & $\begin{array}{c}\text { Nasal curettage. } \\
\text { One CF patient } \\
\text { heterozygous for } \\
\text { Ser1159Pro and F508del. }\end{array}$ & “Lumen-in” configuration. & $\begin{array}{l}\text { Nasospheroids did not swell } \\
\text { in the FIS assay. }\end{array}$ & $\begin{array}{l}\text { Nasospheroids } \\
\text { swelled in } \\
\text { response to } \\
\text { Lumacaftor- } \\
\text { Ivacaftor. } \\
\text { Following ex } \\
\text { vivo studies, } \\
\text { the patients } \\
\text { commenced } \\
\text { in vivo therapy. }\end{array}$ \\
\hline
\end{tabular}


Table 1. Cont.

\begin{tabular}{|c|c|c|c|c|}
\hline Study & Spheroid Model & $\begin{array}{c}\text { Morphology and } \\
\text { Antigen Expression }\end{array}$ & Function & $\begin{array}{c}\text { Pharmacological } \\
\text { Treatment }\end{array}$ \\
\hline $\begin{array}{l}\text { Sachs et al., } \\
2019 \text { [70] }\end{array}$ & $\begin{array}{l}\text { Lung biospies and } \\
\text { BAL specimens } \\
\text { ("bronchospheroids"). } \\
\text { Non-CF and CF subjects. } \\
\text { CF genotypes: } \\
\text { F508el/F508del }(n=3), \\
\text { F508del/G542X }(n=1), \\
\text { R334W/R334W }(n=1) .\end{array}$ & $\begin{array}{l}\text { "Lumen-in" configuration. } \\
\text { Cilia on the } \\
\text { luminal surface. } \\
\text { Positive for basal marker } \\
\text { keratin-5 (KRT5), club cell } \\
\text { marker secretoglobin } \\
\text { family 1A } \\
\text { member } 1 \text { (SCGB1A1), cilia } \\
\text { marker acetylated } \\
\text { a-tubulin, or secretory } \\
\text { cell marker mucin 5AC } \\
\text { (MUC5AC). }\end{array}$ & $\begin{array}{l}\text { In non-CF spheroids, } \\
\text { spheroids swelled upon } \\
\text { forskolin and } \\
E_{\text {act }} \text { stimulation. }\end{array}$ & $\begin{array}{l}\text { Forskolin- } \\
\text { induced swelling } \\
\text { was reduced in } \\
\text { CF compared } \\
\text { to wild-type } \\
\text { spheroids, and } \\
\text { correlated with } \\
\text { the severity of the } \\
\text { tested CFTR } \\
\text { genotypes. It } \\
\text { could be } \\
\text { augmented with } \\
\text { Lumacaftor and } \\
\text { Ivacaftor. Eact } \\
\text { induced a } \\
\text { swelling similar } \\
\text { to that induced } \\
\text { by forskolin. }\end{array}$ \\
\hline $\begin{array}{c}\text { Liu et al., } 2020 \\
\text { [90] }\end{array}$ & $\begin{array}{c}\text { Nasal brushing. } \\
\text { CF }(n=36) \text { and non-CF } \\
(n=12) \text { subjects. } \\
\text { CF genotypes: } \\
\text { F508del/F508del }(n=5) ; \\
\text { others with at least one } \\
\text { minimal or residual } \\
\text { function mutation }\end{array}$ & $\begin{array}{l}\text { "Lumen-in" configuration. } \\
\text { Cilia on the luminal } \\
\text { surface. Positive for } \\
\text { MUC5AC and MUC5B, } \\
\text { ZO-1, CFTR, and FOXI1. }\end{array}$ & $\begin{array}{l}\text { The baseline luminal ratio } \\
\text { and the FIS assay distinguish } \\
\text { between non-CF and CF } \\
\text { spheroids and also between } \\
\text { CF with different genotypes. }\end{array}$ & None. \\
\hline $\begin{array}{l}\text { Amatngalim } \\
\text { et al., } 2021 \text { [96] }\end{array}$ & $\begin{array}{c}\text { Nasal brushing. } \\
\text { CF }(n=22) \text { and CF }(n=22) \\
\text { subjects (F508del/F508del). }\end{array}$ & $\begin{array}{l}\text { 3D spheroids with a } \\
\text { "lumen-in configuration" } \\
\text { derived from 2D } \\
\text { differentiated } \\
\text { ALI-NEC cultures. } \\
\beta \text {-tubulin } \mathrm{IV}^{+} \text {cilia and } \\
\text { MUC5AC } \text { secretory cells } \\
\text { inside of the spheroid and } \\
\text { p63 }{ }^{+} \text {and KRT5 }{ }^{+} \\
\text {basal cells. }\end{array}$ & $\begin{array}{l}\text { FIS measured in non-CF } \\
\text { spheroids was significantly } \\
\text { higher compared to CF } \\
\text { spheroids, while } \mathrm{E}_{\mathrm{act}} \\
\text { induced a more significant } \\
\text { swelling in CF spheroids } \\
\text { compared to non-CF ones. }\end{array}$ & $\begin{array}{l}\text { No response of CF } \\
\text { organoids to } \\
\text { Ivacaftor- } \\
\text { Lumacaftor while } \\
\text { a detectable } \\
\text { swelling was } \\
\text { obtained when } \\
\text { cells were grown } \\
\text { at ALI in the } \\
\text { presence of } \\
\text { neuregulin and } \\
\text { IL-1 } \beta \text {. Under these } \\
\text { conditions, a high } \\
\text { increase in FIS was } \\
\text { obtained with } \\
\text { Ivacaftor- } \\
\text { Tezacaftor- } \\
\text { Elexacaftor treatment. }\end{array}$ \\
\hline
\end{tabular}

\section{Airway Organoids from iPSCs}

iPSCs have the potential for infinite expansion prior to differentiation into airway structures resembling those present in vivo [103-105] and are useful to study CFTR expression, function, and modulation [106-110]. Differentiation protocols of iPSCs for generating proximal or distal lungs have been developed, which include the generation of definitive endoderm (induced using Activin-A and WNT3a), anterior foregut endoderm (BMP, TGF $\beta$, and Wnt inhibitors), early lung endoderm (fetal lung) by applying Wnt BMP, FGF, and retinoic acid signaling, and, lastly, airway progenitors (immature lung) and airway stem cells (mature lung) with club, goblet, multi-ciliated, basal, alveolar, and neuroendocrine cells using Wnt, FGF, c-AMP, and glucocorticoid agonism [105,106,108,109,111]. Under appropriate culture conditions, iPSCs differentiated into airway progenitors can 
self-renew and self-organize into organoids (Figure 1c), which better represent physiologically relevant cell behaviors and in vivo interactions of the native tissue $[65,112,113]$. McCauley et al. [111] have generated iPSC-derived airway organoids via the temporal regulation of WNT signaling, thus isolating highly expressing NK $\times 2-1$ primordial lung progenitors and generating organoids in matrigel. CF-proximalized lung organoids (from F508del homozygous patients) showed defects in forskolin-induced CFTR-dependent swelling, which was rescued by gene editing to correct the F508del mutation back to wild-type CFTR [114]. Using the same differentiation protocol, Berical and colleagues [115] tested the hypothesis that iPSC-derived organoids could be useful in testing pharmaceutical rescuing of CFTR-dependent function across Class 1-3 CFTR mutations. FIS assays in the absence of any modulator showed that G551D organoids displayed statistically significant swelling, whereas no significant swelling was observed in F508del organoids, consistent with their expected baseline levels of CFTR function. Treatment with Ivacaftor of G551D organoids significantly increased their swelling. In F508del organoids, while the treatment with firstgeneration correctors (Lumacaftor, Tezacaftor) had a small effect, a robust increase was observed with the triple combination of Ivacaftor-Tezacaftor-Elexacaftor. The baseline FIS of W12182X organoids was negligible, and treatment with CFTR modulators alone or in combination with G418 (Gentamicin) did not lead to a significant response. However, treatment with G418, SMG1i, and Ivacaftor-Tezacaftor-Elexacaftor led to a significant increase in FIS. To further assess the relevance of the iPSC platform in CF drug testing, the authors demonstrated that iPSC-derived ALI cultures exhibited CFTR-dependent currents and pharmacological rescue at levels comparable to primary HBE cell cultures.

The recent work of Jiang et al. [116] focused on reducing the steps to produce immature lung cells and test them as a platform for drug development in CF by a high-throughput fluorescence-based assay. Moreover, they demonstrated that the CFTR modulators' response in immature iPSC-derived lung cells recapitulates those observed in primary NEC from the same donors. This "shorter" differentiation protocol could be used to generate organoids to be used for a high-throughput testing platform for rarer CFTR mutations. In fact, Wong's lab generated renewable airway organoids from hPSC-derived lung progenitor cells that were reminiscent of early trimester lung development and enriched in basal stem cells [117] (Figure 1c). Furthermore, the FIS assay was also characterized by low sensitivity due to the slow timing, i.e., $>4 \mathrm{~h}$, and often minimal swelling, i.e., often $<10 \%$. Interestingly, airway organoids were "split-open" by plating them onto 96-well plates until the formation of a monolayer of epithelial cells. Then, they were studied by a FLiPR assay to measure CFTR activity, showing that, on average, up to $10 \%$ CFTR function was found. Thus, the open apical chloride conductance (ACC) assay was much more sensitive to detecting CFTRmediated responses, offering an alternative strategy to measure CFTR modulator responses in CF iPSC-derived airway organoids. However, similar to the FIS of airway spheroids, determining the extent to which electrophysiologic measurements in iPSC-derived airway cultures predict disease severity or clinical efficacy of CFTR modulators will be required.

In general, since iPSC-derived airway basal cells can be efficiently cryopreserved for long-term storage while retaining their capacity to form CFTR-expressing airway epithelium in established protocols, the platform lends itself to creating biobanks of $\mathrm{CF}$ iPSC-derived airway basal cells [118], even from individuals with Class I mutations that are presently not amenable to treatment by small molecules-drugs. Like airway spheroids, iPSC-derived airway organoids have to be investigated whether the FIS assay reflects individual disease severity or is predictive of clinical efficacy of CFTR modulators, as others have conducted with the rectal organoid FIS assay [58,119]. Furthermore, it remains unclear how short-term treatment responses individually translate into a long-term clinical response. Finally, the derivation of airway organoids from iPSCs still has to be standardized in regard to differentiation protocols and variability in the generation of differentiated cells [116].

Interestingly, besides drug response, airway organoids would be useful for studying other CF-associated pathophysiological events. For example, Konishi et al. [120] examined 
airway-specific ciliary movement in organoids obtained from ventralized anterior foregut endoderm cells. Airway organoids derived from iPSCs have also been shown to be useful in studying lung infection. Chen et al. [121] demonstrated that infection in vitro with Respiratory Syncytial Virus (RSV), which causes small airway obstruction and bronchiolitis in infants, led to swelling, detachment, and shedding of infected cells into the organoid lumen, similar to what has been observed in the human lung. Therefore, they suggested that iPSC-derived airway organoids may provide a useful tool to model lung disease and infection studies for $\mathrm{CF}$.

Table 2 reports the main morphological and functional characteristics of airway organoids derived from iPSCs and their use in CF research.

Table 2. Airway organoids obtained from induced pluripotent stem cells.

\begin{tabular}{|c|c|c|c|c|}
\hline Study & Organoid Model & $\begin{array}{c}\text { Morphology and } \\
\text { Antigen Expression }\end{array}$ & Function & $\begin{array}{c}\text { Pharmacological } \\
\text { Treatment }\end{array}$ \\
\hline $\begin{array}{l}\text { McCauley } \\
\text { et al., [111] }\end{array}$ & $\begin{array}{c}\text { Proximalized } \\
\text { airway organoids. } \\
\text { One non-CF subject and } \\
\text { two CF patients } \\
\text { homozygous for F508del. }\end{array}$ & $\begin{array}{c}\text { "Lumen-in" } \\
\text { configuration. }\end{array}$ & $\begin{array}{c}\text { Little, if any, swelling } \\
\text { was observed in either } \\
\text { CF lines after exposure to } \\
\text { forskolin as compared to } \\
\text { the wild-type line. }\end{array}$ & $\begin{array}{l}\text { The gene-corrected } \\
\text { F508del/WT } \\
\text { organoids significantly } \\
\text { swelled in response to } \\
\text { forskolin treatment. }\end{array}$ \\
\hline $\begin{array}{c}\text { Berical et al., } \\
\text { [115] }\end{array}$ & $\begin{array}{c}\text { Proximalized } \\
\text { airway organoids. } \\
\text { Three non-CF subjects } \\
\text { and five CF patients } \\
\text { (1 homozygous for } \\
\text { W1282X, three } \\
\text { homozygous for F508del, } \\
\text { one homozygous } \\
\text { for G551D). }\end{array}$ & $\begin{array}{c}\text { “Lumen-in" } \\
\text { configuration. } \\
\text { CFTR expression at } \\
\text { similar levels to primary } \\
\text { HBE cultures }\end{array}$ & $\begin{array}{l}\text { A small but statistically } \\
\text { significant basal swelling } \\
\text { in G551D organoids, but } \\
\text { no detectable basal FIS in } \\
\text { F508del and } \\
\text { W1282X organoids. }\end{array}$ & $\begin{array}{c}\text { FIS increased in G551D } \\
\text { organoids after treatment } \\
\text { with Ivacaftor. } \\
\text { Treatment of F508del } \\
\text { organoids with the } \\
\text { first-generation correctors } \\
\text { (Lumacaftor, Tezacaftor) } \\
\text { had a small effect on FIS, } \\
\text { while a robust increase was } \\
\text { obtained with the triple } \\
\text { combination Ivacaftor- } \\
\text { Tezacaftor-Elexacaftor. } \\
\text { In W1282X organoids, } \\
\text { combinatorial treatment } \\
\text { with G418, SMG1i, and } \\
\text { Ivacaftor-Tezacaftor- } \\
\text { Elexacaftor led to a } \\
\text { significant increase in FIS. }\end{array}$ \\
\hline $\begin{array}{l}\text { Ngan et al., } \\
2021 \text { [117] }\end{array}$ & $\begin{array}{l}\text { Fetal lung-derived } \\
\text { organoids. } \\
\text { Non-CF hiPSC lines. }\end{array}$ & $\begin{array}{c}\text { "Lumen-in" } \\
\text { configuration. } \\
\text { By immunofluorescence: } \\
\text { expression of } \\
\text { basal cell marker KRT5, } \\
\text { ciliated cell } \\
\text { marker FOXJ1, } \\
\text { luminal epithelial cell } \\
\text { marker KRT8, secretory } \\
\text { cell marker MUC16. } \\
\text { By qPCR: expression of } \\
\Delta \text { NP63 and KRT14, } \\
\text { acetylated a-tubulin, } \\
\text { cytokeratin-8/18 } \\
\text { (KRT8/18), and } \\
\text { secretoglobulin 1A1 } \\
\text { (SCGB1A1) and mucin } \\
\text { 5ac (MUC5AC). } \\
\text { CFTR co-expressed at the } \\
\text { lumen side with ZO-1. }\end{array}$ & $\begin{array}{l}\text { The FLiPR analysis on } \\
\text { spheroids } 2-3 \text { days after } \\
\text { seeding on } \\
\text { collagen-coated plates } \\
\text { found an increase in } \\
\text { fluorescence activity } \\
\text { indicative of CFTR } \\
\text { function upon } \\
\text { forskolin-induction } \\
\text { that was inhibited with } \\
\text { CFTR inhibitor-172. } \\
\text { Significant swelling was } \\
\text { found after } 24 \mathrm{~h} \text { of } \\
\text { forskolin stimulation. }\end{array}$ & None. \\
\hline
\end{tabular}




\section{Concluding Remarks}

The personalized medicine approach in CF needs that patient-derived samples from the airways are cultured in a way that is more attainable to reproduce the respiratory microenvironment. Airway cell-based spheroids and organoids are being implemented in the past decades to establish a study model that would guarantee a solid alternative to the gold standard in CF drug studies, i.e., electrophysiological studies in differentiated cultures at ALI conditions. Now it is possible to utilize small amounts of biopsy material that are expanded to millions of cells, which can provide sufficient replicates for moderate-to-high-throughput applications [90]. The CRC methodology will allow improving the procurement of indefinite supply of organoids even more. Importantly, the FIS assay showed a positive correlation with the short-circuit current measurements in HBE from the same patient, revealing robustness of airway organoids similar to that of intestinal ones [58]. Nevertheless, a large variation in FIS measurements was observed because the swelling was limited to well-differentiated spherical structures [70]. Moreover, nasal-derived spheroids required CFTR function measurements over extensive time periods $[68,89,90]$. A further advancement allowed obtaining evenly differentiated spheroids, which are established from ALI-differentiated airway epithelial monolayers, demonstrating scalability that was not obtained before [96]. Interestingly, this method demonstrated that spheroid swelling was in part due to CFTR, while an activator $\left(E_{a c t}\right)$ and inhibitor of TRPV4 showed $\mathrm{Ca}^{2+}$ 's role in mediating CFTR-independent fluid secretion. These results should be confirmed in previously established spheroid cultures as well, thus indicating that fluid transport across these 3D structures should be further analyzed in order to make sense of the CFTR modulator activities. Another interesting finding was that the addition of the pro-inflammatory cytokine IL-1 $\beta$ increased CFTR-dependent swelling, indicating that mimicking the inflammatory environment would be essential to recapitulating the best condition for testing CFTR modulator responses. Indeed, further studies will be necessary to explore whether the CFTR modulator response of nasal spheroids, either formed directly from nasal samples or derived from ALI cultures, are predictive for therapy efficacy in individuals with $\mathrm{CF}$ and how this correlates with other in vitro measurements, i.e., intestinal organoids and 2D ALI differentiated nasal/bronchial airway epithelial cultures [71,77,119]. In this perspective, other novel therapies might also be studied in these 3D models, such as CRISPR-gene editing, read-through agents, or compounds targeting NMD. Indeed, theratyping using NEC cultures, either as ALI or organoids, is no longer limited to those subjects carrying rare, missense CFTR variants, as it is expanding to include nonsense mutations [48]. Moreover, although nasal spheroid/organoid cultures have been utilized for detecting viral infectivity [122], no study has investigated either viral or bacterial responses in the CF context. This will be mandatory to further analyze drug and gene therapies even closer to the patient's situation, i.e., by using the patient's derived spheroids/organoids and bugs obtained from the same patients.

iPSCs-derived airway organoids derived from a single patient may fulfill the need for an unlimited supply of cells and share the epigenetic background of the original cells. Moreover, their capacity to differentiate into a broad spectrum of cell types makes them well suited to in vitro disease modeling. Their relevance in modeling the various developmental stages of the lung would allow better comprehending the effects of molecular defects that affect a newborn CF individual. However, generating such complex 3D structures is not cost-effective, and this technology is not affordable for every laboratory. The optimization of protocols to obtain high and reproducible amounts of lung progenitor cells is warranted. Another issue to be deepened is the contribution of niche stromal cells to the growth and differentiation of epithelial cells, which is underrepresented in current protocols $[55,97]$. Recent data show that robust methods of generating renewable sources of basal stem cells from iPSCs with the capacity to differentiate into multi-epithelial cell types are now available $[117,118]$. Airway organoids derived from these basal stem cells can be used to generate ALI cultures and provide a unique tool to study CFTR function before and after gene correction [118]. On the other hand, these airway organoids possess some drawbacks, 
such as long-term swelling and the lack of rare cell types, including neuroendocrine cells and ionocytes [117]. Therefore, further improvement is needed if iPSC-derived airway organoids might be used to model the CF disease in a more detailed manner. However, the possibility that iPSC-derived organoids can be produced from 2D ALI cultures and, in turn, generate these cultures may allow in the future to develop high-throughput platforms to screen and validate different compounds at the same time.

Airway spheroids and iPSC-derived organoids might be useful to study airway diseases other than CF. Bronchospheroids from lung tumors recapitulate histopathological features as well as cancer gene mutations and were amenable to drug screening [70]. They also allowed modeling of viral infections, such as RSV, presenting in vitro evidence for the direct effects of the viral protein NS2 on cell mobility and fusion and demonstrating the possibility to study neutrophil-epithelium interaction [70]. The recent derivation of airway basal cells from iPSCs and organoids derived thereof may allow modeling airway diseases other than CF, such as asthma and primary ciliary dyskinesia [118]. Asthma was investigated by stimulating the iPSC-derived airway epithelium with the Th2 cytokine IL-13 and inducing mucus metaplasia. Moreover, airway basal cell-derived MCCs were shown to model both the functional and ultrastructural defects observed in DNAH5 mutant primary-donor-derived cells.

In summary, patient-derived nasal/bronchial and iPSC-derived airway organoids show promise to study mechanisms of disease, screen for novel therapeutic approaches, and identify patient responders to currently available therapeutics in a complex environment more similar to the in vivo situation. However, further refinement of expansion and differentiation protocols and screening methods is warranted in the near future.

Author Contributions: M.C. and O.L. conceived and drafted the paper. All authors have read and agreed to the published version of the manuscript.

Funding: This research received no external funding. O.L. was employed on Fondo Sociale EuropeoPON Ricerca e Innovazione 2014-2020, Asse I "Investimenti in capitale umano", Azione 1.2 "Mobilità dei ricercatori"-Linea 2 "Attrazione".

Conflicts of Interest: The authors declare no conflict of interest.

\section{References}

1. Cuevas-Ocana, S.; Laselva, O.; Avolio, J.; Nenna, R. The era of CFTR modulators: Improvements made and remaining challenges. Breathe 2020, 16, 200016. [CrossRef]

2. Dechecchi, M.C.; Tamanini, A.; Cabrini, G. Molecular basis of cystic fibrosis: From bench to bedside. Ann. Transl. Med. 2018, 6, 334. [CrossRef]

3. Lopes-Pacheco, M. CFTR modulators: The changing face of cystic fibrosis in the era of precision medicine. Front. Pharmacol. 2019, 10, 1662. [CrossRef]

4. De Boeck, K.; Amaral, M.D. Progress in therapies for cystic fibrosis. Lancet Respir. Med. 2016, 4, 662-674. [CrossRef]

5. Veit, G.; Avramescu, R.G.; Chiang, A.N.; Houck, S.A.; Cai, Z.; Peters, K.W.; Hong, J.S.; Pollard, H.B.; Guggino, W.B.; Balch, W.E.; et al. From CFTR biology toward combinatorial pharmacotherapy: Expanded classification of cystic fibrosis mutations. Mol. Biol. Cell 2016, 27, 424-433. [CrossRef] [PubMed]

6. Barbry, P.; Cavard, A.; Chanson, M.; Jaffe, A.B.; Plasschaert, L.W. Regeneration of airway epithelial cells to study rare cell states in cystic fibrosis. J. Cyst. Fibros. 2020, 19, S42-S46. [CrossRef] [PubMed]

7. Okuda, K.; Dang, H.; Kobayashi, Y.; Carraro, G.; Nakano, S.; Chen, G.; Kato, T.; Asakura, T.; Gilmore, R.C.; Morton, L.C.; et al. Secretory cells dominate airway CFTR expression and function in human airway superficial epithelia. Am. J. Respir. Crit. Care Med. 2021, 203, 1275-1289. [CrossRef] [PubMed]

8. Montoro, D.T.; Haber, A.L.; Biton, M.; Vinarsky, V.; Lin, B.; Birket, S.E.; Yuan, F.; Chen, S.; Leung, H.M.; Villoria, J.; et al. A revised airway epithelial hierarchy includes CFTR-expressing ionocytes. Nature 2018, 560, 319-324. [CrossRef] [PubMed]

9. Plasschaert, L.W.; Zilionis, R.; Choo-Wing, R.; Savova, V.; Knehr, J.; Roma, G.; Klein, A.M.; Jaffe, A.B. A single-cell atlas of the airway epithelium reveals the CFTR-rich pulmonary ionocyte. Nature 2018, 560, 377-381. [CrossRef]

10. Boucher, R.C. Evidence for airway surface dehydration as the initiating event in CF airway disease. J. Intern. Med. 2007, 261, 5-16. [CrossRef]

11. Stoltz, D.A.; Meyerholz, D.K.; Welsh, M.J. Origins of cystic fibrosis lung disease. N. Engl. J. Med. 2015, 372, 351-362. [CrossRef]

12. Hobbs, C.A.; Da Tan, C.; Tarran, R. Does epithelial sodium channel hyperactivity contribute to cystic fibrosis lung disease? J. Physiol. 2013, 591, 4377-4387. [CrossRef] 
13. Elborn, J.S. Cystic fibrosis. Lancet 2016, 388, 2519-2531. [CrossRef]

14. Bergeron, C.; Cantin, A.M. New therapies to correct the cystic fibrosis basic defect. Int. J. Mol. Sci. 2021, 22, 6193. [CrossRef] [PubMed]

15. Van Goor, F.; Hadida, S.; Grootenhuis, P.D.; Burton, B.; Stack, J.H.; Straley, K.S.; Decker, C.J.; Miller, M.; McCartney, J.; Olson, E.R.; et al. Correction of the F508del-CFTR protein processing defect in vitro by the investigational drug VX-809. Proc. Natl. Acad. Sci. USA 2011, 108, 18843-18848. [CrossRef] [PubMed]

16. Wainwright, C.E.; Elborn, J.S.; Ramsey, B.W. Lumacaftor-Ivacaftor in patients with cystic fibrosis homozygous for Phe508del CFTR. N. Engl. J. Med. 2015, 373, 1783-1784. [CrossRef] [PubMed]

17. Taylor-Cousar, J.L.; Munck, A.; McKone, E.F.; van der Ent, C.K.; Moeller, A.; Simard, C.; Wang, L.T.; Ingenito, E.P.; McKee, C.; Lu, Y.; et al. Tezacaftor-Ivacaftor in patients with cystic fibrosis homozygous for Phe508del. N. Engl. J. Med. 2017, 377, 2013-2023. [CrossRef] [PubMed]

18. Keating, D.; Marigowda, G.; Burr, L.; Daines, C.; Mall, M.A.; McKone, E.F.; Ramsey, B.W.; Rowe, S.M.; Sass, L.A.; Tullis, E.; et al. VX-445-Tezacaftor-Iivacaftor in patients with cystic fibrosis and one or two Phe508del alleles. N. Engl. J. Med. 2018, 379, 1612-1620. [CrossRef] [PubMed]

19. Veit, G.; Roldan, A.; Hancock, M.A.; Da Fonte, D.F.; Xu, H.; Hussein, M.; Frenkiel, S.; Matouk, E.; Velkov, T.; Lukacs, G.L. Allosteric folding correction of F508del and rare CFTR mutants by elexacaftor-tezacaftor-ivacaftor (Trikafta) combination. JCI Insight 2020, 5, e139983. [CrossRef]

20. Laselva, O.; Bartlett, C.; Gunawardena, T.N.A.; Ouyang, H.; Eckford, P.D.W.; Moraes, T.J.; Bear, C.E.; Gonska, T. Rescue of multiple class II CFTR mutations by elexacaftor+tezacaftor+ivacaftor mediated in part by the dual activities of elexacaftor as both corrector and potentiator. Eur. Respir. J. 2021, 57, 2002774. [CrossRef]

21. Laselva, O.; Ardelean, M.C.; Bear, C.E. Phenotyping rare CFTR mutations reveal functional expression defects restored by TRIKAFTA. J. Pers. Med. 2021, 11, 301. [CrossRef]

22. Yang, S.J.; Chen, H.M.; Hsieh, C.H.; Hsu, J.T.; Yeh, C.N.; Yeh, T.S.; Hwang, T.L.; Jan, Y.Y.; Chen, M.F. Akt pathway is required for oestrogen-mediated attenuation of lung injury in a rodent model of cerulein-induced acute pancreatitis. Injury 2011, 42, 638-642. [CrossRef]

23. Accurso, F.J.; Rowe, S.M.; Clancy, J.P.; Boyle, M.P.; Dunitz, J.M.; Durie, P.R.; Sagel, S.D.; Hornick, D.B.; Konstan, M.W.; Donaldson, S.H.; et al. Effect of VX-770 in persons with cystic fibrosis and the G551D-CFTR mutation. N. Engl. J. Med. 2010, 363, 1991-2003. [CrossRef]

24. Davies, J.C.; Moskowitz, S.M.; Brown, C.; Horsley, A.; Mall, M.A.; McKone, E.F.; Plant, B.J.; Prais, D.; Ramsey, B.W.; Taylor-Cousar, J.L.; et al. VX-659-Tezacaftor-Ivacaftor in patients with cystic fibrosis and one or two Phe508del alleles. N. Engl. J. Med. 2018, 379, 1599-1611. [CrossRef]

25. Middleton, P.G.; Mall, M.A.; Drevinek, P.; Lands, L.C.; McKone, E.F.; Polineni, D.; Ramsey, B.W.; Taylor-Cousar, J.L.; Tullis, E.; Vermeulen, F.; et al. Elexacaftor-Tezacaftor-Ivacaftor for cystic fibrosis with a single Phe508del allele. N. Engl. J. Med. 2019, 381, 1809-1819. [CrossRef]

26. Ramsey, B.W.; Davies, J.; McElvaney, N.G.; Tullis, E.; Bell, S.C.; Drevinek, P.; Griese, M.; McKone, E.F.; Wainwright, C.E.; Konstan, M.W.; et al. A CFTR potentiator in patients with cystic fibrosis and the G551D mutation. N. Engl. J. Med. 2011, 365, 1663-1672. [CrossRef]

27. Wainwright, C.E.; Elborn, J.S.; Ramsey, B.W.; Marigowda, G.; Huang, X.; Cipolli, M.; Colombo, C.; Davies, J.C.; De Boeck, K.; Flume, P.A.; et al. Lumacaftor-Ivacaftor in patients with cystic fibrosis homozygous for Phe508del CFTR. N. Engl. J. Med. 2015, 373, 220-231. [CrossRef] [PubMed]

28. Mendell, J.T.; Sharifi, N.A.; Meyers, J.L.; Martinez-Murillo, F.; Dietz, H.C. Nonsense surveillance regulates expression of diverse classes of mammalian transcripts and mutes genomic noise. Nat. Genet. 2004, 36, 1073-1078. [CrossRef]

29. Bedwell, D.M.; Kaenjak, A.; Benos, D.J.; Bebok, Z.; Bubien, J.K.; Hong, J.; Tousson, A.; Clancy, J.P.; Sorscher, E.J. Suppression of a CFTR premature stop mutation in a bronchial epithelial cell line. Nat. Med. 1997, 3, 1280-1284. [CrossRef] [PubMed]

30. Valley, H.C.; Bukis, K.M.; Bell, A.; Cheng, Y.; Wong, E.; Jordan, N.J.; Allaire, N.E.; Sivachenko, A.; Liang, F.; Bihler, H.; et al. Isogenic cell models of cystic fibrosis-causing variants in natively expressing pulmonary epithelial cells. J. Cyst. Fibros. 2019, 18, 476-483. [CrossRef] [PubMed]

31. Crawford, D.K.; Mullenders, J.; Pott, J.; Boj, S.F.; Landskroner-Eiger, S.; Goddeeris, M.M. Targeting G542X CFTR nonsense alleles with ELX-02 restores CFTR function in human-derived intestinal organoids. J. Cyst. Fibros. 2021, 20, 436-442. [CrossRef]

32. Aksit, M.A.; Bowling, A.D.; Evans, T.A.; Joynt, A.T.; Osorio, D.; Patel, S.; West, N.; Merlo, C.; Sosnay, P.R.; Cutting, G.R.; et al. Decreased mRNA and protein stability of W1282X limits response to modulator therapy. J. Cyst. Fibros. 2019, 18, 606-613. [CrossRef]

33. Keenan, M.M.; Huang, L.; Jordan, N.J.; Wong, E.; Cheng, Y.; Valley, H.C.; Mahiou, J.; Liang, F.; Bihler, H.; Mense, M.; et al. Nonsense-mediated RNA decay pathway inhibition restores expression and function of W1282X CFTR. Am. J. Respir. Cell Mol. Biol. 2019, 61, 290-300. [CrossRef]

34. Laselva, O.; Eckford, P.D.; Bartlett, C.; Ouyang, H.; Gunawardena, T.N.; Gonska, T.; Moraes, T.J.; Bear, C.E. Functional rescue of c.3846G $>$ A (W1282X) in patient-derived nasal cultures achieved by inhibition of nonsense mediated decay and protein modulators with complementary mechanisms of action. J. Cyst. Fibros. 2020, 19, 717-727. [CrossRef] 
35. Cao, H.; Ouyang, H.; Laselva, O.; Bartlett, C.; Zhou, Z.P.; Duan, C.; Gunawardena, T.; Avolio, J.; Bear, C.E.; Gonska, T.; et al. A helper-dependent adenoviral vector rescues CFTR to wild-type functional levels in cystic fibrosis epithelial cells harbouring class I mutations. Eur. Respir. J. 2020, 56, 2000205. [CrossRef] [PubMed]

36. Erwood, S.; Laselva, O.; Bily, T.M.I.; Brewer, R.A.; Rutherford, A.H.; Bear, C.E.; Ivakine, E.A. Allele-specific prevention of nonsensemediated decay in cystic fibrosis using homology-independent genome editing. Mol. Ther. Methods Clin. Dev. 2020, 17, 1118-1128. [CrossRef] [PubMed]

37. Santos, L.; Mention, K.; Cavusoglu-Doran, K.; Sanz, D.J.; Bacalhau, M.; Lopes-Pacheco, M.; Harrison, P.T.; Farinha, C.M. Comparison of Cas9 and Cas12a CRISPR editing methods to correct the W1282X-CFTR mutation. J. Cyst. Fibros. 2021, 21, S1569-S1993.

38. Bandara, R.A.; Chen, Z.R.; Hu, J. Potential of helper-dependent adenoviral vectors in CRISPR-cas9-mediated lung gene therapy. Cell Biosci. 2021, 11, 145. [CrossRef] [PubMed]

39. Allan, K.M.; Farrow, N.; Donnelley, M.; Jaffe, A.; Waters, S.A. Treatment of cystic fibrosis: From gene- to cell-based therapies. Front. Pharmacol. 2021, 12, 639475. [CrossRef] [PubMed]

40. King, N.E.; Suzuki, S.; Barilla, C.; Hawkins, F.J.; Randell, S.H.; Reynolds, S.D.; Stripp, B.R.; Davis, B.R. Correction of airway stem cells: Genome editing approaches for the treatment of cystic fibrosis. Hum. Gene Ther. 2020, 31, 956-972. [CrossRef]

41. McCarron, A.; Donnelley, M.; Parsons, D. Airway disease phenotypes in animal models of cystic fibrosis. Respir. Res. 2018, 19 , 54. [CrossRef]

42. Mou, H.; Brazauskas, K.; Rajagopal, J. Personalized medicine for cystic fibrosis: Establishing human model systems. Pediatr. Pulmonol. 2015, 50, S14-S23. [CrossRef]

43. Van Goor, F.; Yu, H.; Burton, B.; Hoffman, B.J. Effect of ivacaftor on CFTR forms with missense mutations associated with defects in protein processing or function. J. Cyst. Fibros. 2014, 13, 29-36. [CrossRef]

44. Veit, G.; Xu, H.; Dreano, E.; Avramescu, R.G.; Bagdany, M.; Beitel, L.K.; Roldan, A.; Hancock, M.A.; Lay, C.; Li, W.; et al. Structure-guided combination therapy to potently improve the function of mutant CFTRs. Nat. Med. 2018, 24, 1732-1742. [CrossRef] [PubMed]

45. Pedemonte, N.; Tomati, V.; Sondo, E.; Galietta, L.J. Influence of cell background on pharmacological rescue of mutant CFTR. Am. J. Physiol. -Cell Physiol. 2010, 298, C866-C874. [CrossRef]

46. Haggie, P.M.; Phuan, P.W.; Tan, J.A.; Xu, H.; Avramescu, R.G.; Perdomo, D.; Zlock, L.; Nielson, D.W.; Finkbeiner, W.E.; Lukacs, G.L.; et al. Correctors and potentiators rescue function of the truncated W1282X-cystic fibrosis transmembrane regulator (CFTR) translation product. J. Biol. Chem. 2017, 292, 771-785. [CrossRef] [PubMed]

47. Castellani, S.; Di Gioia, S.; di Toma, L.; Conese, M. Human cellular models for the investigation of lung inflammation and mucus production in cystic fibrosis. Anal. Cell. Pathol. 2018, 2018, 3839803. [CrossRef] [PubMed]

48. Keegan, D.E.; Brewington, J.J. Nasal epithelial cell-based models for individualized study in cystic fibrosis. Int. J. Mol. Sci. 2021, 22, 4448. [CrossRef] [PubMed]

49. Clancy, J.P.; Cotton, C.U.; Donaldson, S.H.; Solomon, G.M.; VanDevanter, D.R.; Boyle, M.P.; Gentzsch, M.; Nick, J.A.; Illek, B.; Wallenburg, J.C.; et al. CFTR modulator theratyping: Current status, gaps and future directions. J. Cyst. Fibros. 2019, 18, 22-34. [CrossRef] [PubMed]

50. Dousmanis, A.G.; Nairn, A.C.; Gadsby, D.C. Distinct $\mathrm{Mg}^{2+}$-dependent steps rate limit opening and closing of a single CFTR $\mathrm{Cl}^{-}$ channel. J. Gen. Physiol. 2002, 119, 545-559. [CrossRef]

51. Devor, D.C.; Bridges, R.J.; Pilewski, J.M. Pharmacological modulation of ion transport across wild-type and deltaf508 CFTRexpressing human bronchial epithelia. Am. J. Physiol. -Cell Physiol. 2000, 279, C461-C479. [CrossRef] [PubMed]

52. Randell, S.H.; Fulcher, M.L.; O'Neal, W.; Olsen, J.C. Primary epithelial cell models for cystic fibrosis research. Methods Mol. Biol. 2011, 742, 285-310.

53. Gkatzis, K.; Taghizadeh, S.; Huh, D.; Stainier, D.Y.R.; Bellusci, S. Use of three-dimensional organoids and lung-on-a-chip methods to study lung development, regeneration and disease. Eur. Respir. J. 2018, 52, 1800876. [CrossRef]

54. Lu, T.; Cao, Y.; Zhao, P.; Shen, S.; Xi, Y. Organoid: A powerful tool to study lung regeneration and disease. Cell Regen 2021, 10, 21. [CrossRef]

55. van der Vaart, J.; Clevers, H. Airway organoids as models of human disease. J. Intern. Med. 2021, 289, 604-613. [CrossRef]

56. Nikolic, M.Z.; Rawlins, E.L. Lung organoids and their use to study cell-cell interaction. Curr. Pathobiol. Rep. 2017, 5, $223-231$. [CrossRef]

57. Dekkers, J.F.; Wiegerinck, C.L.; de Jonge, H.R.; Bronsveld, I.; Janssens, H.M.; de Winter-de Groot, K.M.; Brandsma, A.M.; de Jong, N.W.; Bijvelds, M.J.; Scholte, B.J.; et al. A functional CFTR assay using primary cystic fibrosis intestinal organoids. Nat. Med. 2013, 19, 939-945. [CrossRef]

58. Dekkers, J.F.; Berkers, G.; Kruisselbrink, E.; Vonk, A.; de Jonge, H.R.; Janssens, H.M.; Bronsveld, I.; van de Graaf, E.A.; Nieuwenhuis, E.E.; Houwen, R.H.; et al. Characterizing responses to CFTR-modulating drugs using rectal organoids derived from subjects with cystic fibrosis. Sci. Transl. Med. 2016, 8, 344ra84. [CrossRef]

59. van Mourik, P.; Beekman, J.M.; van der Ent, C.K. Intestinal organoids to model cystic fibrosis. Eur. Respir. J. 2019, 54, 1802379. [CrossRef] [PubMed]

60. Dekkers, J.F.; Gogorza Gondra, R.A.; Kruisselbrink, E.; Vonk, A.M.; Janssens, H.M.; de Winter-de Groot, K.M.; van der Ent, C.K.; Beekman, J.M. Optimal correction of distinct CFTR folding mutants in rectal cystic fibrosis organoids. Eur. Respir. J. 2016, 48, 451-458. [CrossRef] [PubMed] 
61. Ramalho, A.S.; Furstova, E.; Vonk, A.M.; Ferrante, M.; Verfaillie, C.; Dupont, L.; Boon, M.; Proesmans, M.; Beekman, J.M.; Sarouk, I.; et al. Correction of CFTR function in intestinal organoids to guide treatment of cystic fibrosis. Eur. Respir. J. 2021, 57, 1902426. [CrossRef]

62. Graeber, S.Y.; van Mourik, P.; Vonk, A.M.; Kruisselbrink, E.; Hirtz, S.; van der Ent, C.K.; Mall, M.A.; Beekman, J.M. Comparison of organoid swelling and in vivo biomarkers of CFTR function to determine effects of lumacaftor-ivacaftor in patients with cystic fibrosis homozygous for the F508del mutation. Am. J. Respir. Crit. Care Med. 2020, 202, 1589-1592. [CrossRef]

63. Zomer-van Ommen, D.D.; de Poel, E.; Kruisselbrink, E.; Oppelaar, H.; Vonk, A.M.; Janssens, H.M.; van der Ent, C.K.; Hagemeijer, M.C.; Beekman, J.M. Comparison of ex vivo and in vitro intestinal cystic fibrosis models to measure CFTR-dependent ion channel activity. J. Cyst. Fibros. 2018, 17, 316-324. [CrossRef]

64. Xia, S.; Bozóky, Z.; Laselva, O.; Di Paola, M.; Ahmadi, S.; Jiang, J.X.; Pitstick, A.; Jiang, C.; Rotin, D.; Mayhew, C.N.; et al. High-throughput functional analysis of CFTR and other apically localized channels in iPSC derived intestinal organoids. bioRxiv 2021. [CrossRef]

65. Gotoh, S.; Ito, I.; Nagasaki, T.; Yamamoto, Y.; Konishi, S.; Korogi, Y.; Matsumoto, H.; Muro, S.; Hirai, T.; Funato, M.; et al. Generation of alveolar epithelial spheroids via isolated progenitor cells from human pluripotent stem cells. Stem Cell Rep. 2014, 3, 394-403. [CrossRef]

66. Barkauskas, C.E.; Cronce, M.J.; Rackley, C.R.; Bowie, E.J.; Keene, D.R.; Stripp, B.R.; Randell, S.H.; Noble, P.W.; Hogan, B.L. Type 2 alveolar cells are stem cells in adult lung. J. Clin. Investig. 2013, 123, 3025-3036. [CrossRef]

67. Castillon, N.; Hinnrasky, J.; Zahm, J.M.; Kaplan, H.; Bonnet, N.; Corlieu, P.; Klossek, J.M.; Taouil, K.; Avril-Delplanque, A.; Peault, B.; et al. Polarized expression of cystic fibrosis transmembrane conductance regulator and associated epithelial proteins during the regeneration of human airway surface epithelium in three-dimensional culture. Lab. Investig. 2002, 82, 989-998. [CrossRef] [PubMed]

68. Guimbellot, J.S.; Leach, J.M.; Chaudhry, I.G.; Quinney, N.L.; Boyles, S.E.; Chua, M.; Aban, I.; Jaspers, I.; Gentzsch, M. Nasospheroids permit measurements of CFTR-dependent fluid transport. JCI Insight 2017, 2, e95734. [CrossRef]

69. Hild, M.; Jaffe, A.B. Production of 3-D airway organoids from primary human airway basal cells and their use in high-throughput screening. Curr. Protoc. Stem Cell Biol. 2016, 37, IE.9.1-IE.9.15. [CrossRef] [PubMed]

70. Sachs, N.; Papaspyropoulos, A.; Zomer-van Ommen, D.D.; Heo, I.; Bottinger, L.; Klay, D.; Weeber, F.; Huelsz-Prince, G.; Iakobachvili, N.; Amatngalim, G.D.; et al. Long-term expanding human airway organoids for disease modeling. EMBO J. 2019, 38, e100300. [CrossRef] [PubMed]

71. Pranke, I.M.; Hatton, A.; Simonin, J.; Jais, J.P.; Le Pimpec-Barthes, F.; Carsin, A.; Bonnette, P.; Fayon, M.; Stremler-Le Bel, N.; Grenet, D.; et al. Correction of CFTR function in nasal epithelial cells from cystic fibrosis patients predicts improvement of respiratory function by CFTR modulators. Sci. Rep. 2017, 7, 7375. [CrossRef]

72. Molinski, S.V.; Ahmadi, S.; Ip, W.; Ouyang, H.; Villella, A.; Miller, J.P.; Lee, P.S.; Kulleperuma, K.; Du, K.; Di Paola, M.; et al. Orkambi(R) and amplifier co-therapy improves function from a rare CFTR mutation in gene-edited cells and patient tissue. EMBO Mol. Med. 2017, 9, 1224-1243. [CrossRef] [PubMed]

73. Wu, Y.S.; Jiang, J.; Ahmadi, S.; Lew, A.; Laselva, O.; Xia, S.; Bartlett, C.; Ip, W.; Wellhauser, L.; Ouyang, H.; et al. ORKAMBImediated rescue of mucociliary clearance in cystic fibrosis primary respiratory cultures is enhanced by arginine uptake, arginase inhibition, and promotion of nitric oxide signaling to the cystic fibrosis transmembrane conductance regulator channel. Mol. Pharmacol. 2019, 96, 515-525. [CrossRef] [PubMed]

74. Oren, Y.S.; Irony-Tur Sinai, M.; Golec, A.; Barchad-Avitzur, O.; Mutyam, V.; Li, Y.; Hong, J.; Ozeri-Galai, E.; Hatton, A.; Leibson, C.; et al. Antisense oligonucleotide-based drug development for cystic fibrosis patients carrying the $3849+10 \mathrm{~kb}$ C-to-T splicing mutation. J. Cyst. Fibros. 2021, 20, 865-875. [CrossRef]

75. Brewington, J.J.; Filbrandt, E.T.; LaRosa, F.J., 3rd; Moncivaiz, J.D.; Ostmann, A.J.; Strecker, L.M.; Clancy, J.P. Brushed nasal epithelial cells are a surrogate for bronchial epithelial CFTR studies. JCI Insight 2018, 3, e99385. [CrossRef]

76. Clarke, L.A.; Sousa, L.; Barreto, C.; Amaral, M.D. Changes in transcriptome of native nasal epithelium expressing F508del-CFTR and intersecting data from comparable studies. Respir. Res. 2013, 14, 38. [CrossRef] [PubMed]

77. Pranke, I.; Hatton, A.; Masson, A.; Flament, T.; Le Bourgeois, M.; Chedevergne, F.; Bailly, C.; Urbach, V.; Hinzpeter, A.; Edelman, A.; et al. Might brushed nasal cells be a surrogate for CFTR modulator clinical response? Am. J. Respir. Crit. Care Med. 2019, 199, 123-126. [CrossRef] [PubMed]

78. Silva, I.A.L.; Railean, V.; Duarte, A.; Amaral, M.D. Personalized medicine based on nasal epithelial cells: Comparative studies with rectal biopsies and intestinal organoids. J. Pers. Med. 2021, 11, 421. [CrossRef]

79. Martinovich, K.M.; Iosifidis, T.; Buckley, A.G.; Looi, K.; Ling, K.M.; Sutanto, E.N.; Kicic-Starcevich, E.; Garratt, L.W.; Shaw, N.C.; Montgomery, S.; et al. Conditionally reprogrammed primary airway epithelial cells maintain morphology, lineage and disease specific functional characteristics. Sci. Rep. 2017, 7, 17971. [CrossRef]

80. Chapman, S.; Liu, X.; Meyers, C.; Schlegel, R.; McBride, A.A. Human keratinocytes are efficiently immortalized by a Rho kinase inhibitor. J. Clin. Investig. 2010, 120, 2619-2626. [CrossRef]

81. Bukowy-Bieryllo, Z. Long-term differentiating primary human airway epithelial cell cultures: How far are we? Cell Commun. Signal. 2021, 19, 63. [CrossRef] [PubMed]

82. Mou, H.; Vinarsky, V.; Tata, P.R.; Brazauskas, K.; Choi, S.H.; Crooke, A.K.; Zhang, B.; Solomon, G.M.; Turner, B.; Bihler, H.; et al. Dual SMAD signaling inhibition enables long-term expansion of diverse epithelial basal cells. Cell Stem Cell 2016, 19, 217-231. [CrossRef] 
83. Awatade, N.T.; Wong, S.L.; Capraro, A.; Pandzic, E.; Slapetova, I.; Zhong, L.; Turgutoglu, N.; Fawcett, L.K.; Whan, R.M.; Jaffe, A.; et al. Significant functional differences in differentiated conditionally reprogrammed (CRC)- and feeder-free dual SMAD inhibited-expanded human nasal epithelial cells. J. Cyst. Fibros. 2021, 20, 364-371. [CrossRef] [PubMed]

84. Pedersen, P.S.; Procida, K.; Larsen, P.L.; Holstein-Rathlou, N.H.; Frederiksen, O. Water permeability in human airway epithelium. Pflugers. Arch. 2005, 451, 464-473. [CrossRef] [PubMed]

85. Bridges, M.A.; Walker, D.C.; Harris, R.A.; Wilson, B.R.; Davidson, A.G. Cultured human nasal epithelial multicellular spheroids: Polar cyst-like model tissues. Biochem. Cell Biol. 1991, 69, 102-108. [CrossRef] [PubMed]

86. Marthin, J.K.; Stevens, E.M.; Larsen, L.A.; Christensen, S.T.; Nielsen, K.G. Patient-specific three-dimensional explant spheroids derived from human nasal airway epithelium: A simple methodological approach for ex vivo studies of primary ciliary dyskinesia. Cilia 2017, 6, 3. [CrossRef] [PubMed]

87. Neugebauer, P.; Endepols, H.; Mickenhagen, A.; Walger, M. Ciliogenesis in submersion and suspension cultures of human nasal epithelial cells. Eur. Arch. Otorhinolaryngol. 2003, 260, 325-330. [CrossRef]

88. Gamarra, F.; Bergner, A.; Stauss, E.; Stocker, I.; Grundler, S.; Huber, R.M. Rotation frequency of human bronchial and nasal epithelial spheroids as an indicator of mucociliary function. Respiration 2006, 73, 664-672. [CrossRef]

89. Brewington, J.J.; Filbrandt, E.T.; LaRosa, F.J., 3rd; Ostmann, A.J.; Strecker, L.M.; Szczesniak, R.D.; Clancy, J.P. Detection of CFTR function and modulation in primary human nasal cell spheroids. J. Cyst. Fibros. 2018, 17, 26-33. [CrossRef]

90. Liu, Z.; Anderson, J.D.; Deng, L.; Mackay, S.; Bailey, J.; Kersh, L.; Rowe, S.M.; Guimbellot, J.S. Human nasal epithelial organoids for therapeutic development in cystic fibrosis. Genes 2020, 11, 603. [CrossRef]

91. Awatade, N.T.; Wong, S.L.; Hewson, C.K.; Fawcett, L.K.; Kicic, A.; Jaffe, A.; Waters, S.A. Human primary epithelial cell models: Promising tools in the era of cystic fibrosis personalized medicine. Front. Pharmacol. 2018, 9, 1429. [CrossRef]

92. Pedersen, P.S.; Frederiksen, O.; Holstein-Rathlou, N.H.; Larsen, P.L.; Qvortrup, K. Ion transport in epithelial spheroids derived from human airway cells. Am. J. Physiol. -Lung Cell. Mol. Physiol. 1999, 276, L75-L80. [CrossRef] [PubMed]

93. Pedersen, P.S.; Holstein-Rathlou, N.H.; Larsen, P.L.; Qvortrup, K.; Frederiksen, O. Fluid absorption related to ion transport in human airway epithelial spheroids. Am. J. Physiol. -Lung Cell. Mol. Physiol. 1999, 277, L1096-L1103. [CrossRef]

94. Pedersen, P.S.; Braunstein, T.H.; Jorgensen, A.; Larsen, P.L.; Holstein-Rathlou, N.H.; Frederiksen, O. Stimulation of aquaporin-5 and transepithelial water permeability in human airway epithelium by hyperosmotic stress. Pflügers Arch. -Eur. J. Physiol. 2007, 453, 777-785. [CrossRef] [PubMed]

95. McCarthy, C.; Brewington, J.J.; Harkness, B.; Clancy, J.P.; Trapnell, B.C. Personalised CFTR pharmacotherapeutic response testing and therapy of cystic fibrosis. Eur. Respir. J. 2018, 51, 1702457. [CrossRef] [PubMed]

96. Amatngalim, G.D.; Rodenburg, L.W.; Aalbers, B.L.; Raeven, H.H.M.; Aarts, E.M.; Silva, I.A.L.; Nijenhuis, W.; Vrendenbarg, S.; Kruisselbrink, E.; Brunsveld, J.E.; et al. CFTR modulator response measurements in subjects with cystic fibrosis using 2D differentiated nasal epithelia converted into spheroids. bioRxiv 2021. [CrossRef]

97. Barkauskas, C.E.; Chung, M.I.; Fioret, B.; Gao, X.; Katsura, H.; Hogan, B.L. Lung organoids: Current uses and future promise. Development 2017, 144, 986-997. [CrossRef] [PubMed]

98. Tan, Q.; Choi, K.M.; Sicard, D.; Tschumperlin, D.J. Human airway organoid engineering as a step toward lung regeneration and disease modeling. Biomaterials 2017, 113, 118-132. [CrossRef]

99. Danahay, H.; Pessotti, A.D.; Coote, J.; Montgomery, B.E.; Xia, D.; Wilson, A.; Yang, H.; Wang, Z.; Bevan, L.; Thomas, C.; et al. Notch2 is required for inflammatory cytokine-driven goblet cell metaplasia in the lung. Cell Rep. 2015, 10, 239-252. [CrossRef]

100. Rock, J.R.; Onaitis, M.W.; Rawlins, E.L.; Lu, Y.; Clark, C.P.; Xue, Y.; Randell, S.H.; Hogan, B.L. Basal cells as stem cells of the mouse trachea and human airway epithelium. Proc. Natl. Acad. Sci. USA 2009, 106, 12771-12775. [CrossRef]

101. Sprott, R.F.; Ritzmann, F.; Langer, F.; Yao, Y.; Herr, C.; Kohl, Y.; Tschernig, T.; Bals, R.; Beisswenger, C. Flagellin shifts 3D bronchospheres towards mucus hyperproduction. Respir. Res. 2020, 21, 222. [CrossRef] [PubMed]

102. Ramalho, A.S.; Vonk, A.M.; Silva, I.A.; Botelho, H.M.; Bor, R.V.; van Mourik, P.; Heida-Michel, S.; Aguilera, B.; Mullenders, J.; Boj, S.F.; et al. High reproducibility of forskolin-induced swelling of intestinal organoids across three academic laboratories. Pediatric. Pulmonol. 2019, 54, S326.

103. Wilkinson, D.C.; Alva-Ornelas, J.A.; Sucre, J.M.; Vijayaraj, P.; Durra, A.; Richardson, W.; Jonas, S.J.; Paul, M.K.; Karumbayaram, S.; Dunn, B.; et al. Development of a three-dimensional bioengineering technology to generate lung tissue for personalized disease modeling. Stem Cells Transl. Med. 2017, 6, 622-633. [CrossRef] [PubMed]

104. Green, M.D.; Chen, A.; Nostro, M.C.; d'Souza, S.L.; Schaniel, C.; Lemischka, I.R.; Gouon-Evans, V.; Keller, G.; Snoeck, H.W. Generation of anterior foregut endoderm from human embryonic and induced pluripotent stem cells. Nat. Biotechnol. 2011, 29, 267-272. [CrossRef]

105. Huang, S.X.; Islam, M.N.; O’Neill, J.; Hu, Z.; Yang, Y.G.; Chen, Y.W.; Mumau, M.; Green, M.D.; Vunjak-Novakovic, G.; Bhattacharya, J.; et al. Efficient generation of lung and airway epithelial cells from human pluripotent stem cells. Nat. Biotechnol. 2014, 32, 84-91. [CrossRef] [PubMed]

106. Mou, H.; Zhao, R.; Sherwood, R.; Ahfeldt, T.; Lapey, A.; Wain, J.; Sicilian, L.; Izvolsky, K.; Musunuru, K. Generation of multipotent lung and airway progenitors from mouse ESCs and patient-specific cystic fibrosis iPSCs. Cell Stem Cell 2012, 10, 385-397. [CrossRef] [PubMed] 
107. Wong, A.P.; Bear, C.E.; Chin, S.; Pasceri, P.; Thompson, T.O.; Huan, L.J.; Ratjen, F.; Ellis, J.; Rossant, J. Directed differentiation of human pluripotent stem cells into mature airway epithelia expressing functional CFTR protein. Nat. Biotechnol. 2012, 30, 876-882. [CrossRef]

108. Wong, A.P.; Chin, S.; Xia, S.; Garner, J.; Bear, C.E.; Rossant, J. Efficient generation of functional CFTR-expressing airway epithelial cells from human pluripotent stem cells. Nat. Protoc. 2015, 10, 363-381. [CrossRef]

109. Firth, A.L.; Dargitz, C.T.; Qualls, S.J.; Menon, T.; Wright, R.; Singer, O.; Gage, F.H.; Khanna, A.; Verma, I.M. Generation of multiciliated cells in functional airway epithelia from human induced pluripotent stem cells. Proc. Natl. Acad. Sci. USA 2014, 111, E1723-E1730. [CrossRef]

110. Firth, A.L.; Menon, T.; Parker, G.S.; Qualls, S.J.; Lewis, B.M.; Ke, E.; Dargitz, C.T.; Wright, R.; Khanna, A.; Gage, F.H.; et al. Functional gene correction for cystic fibrosis in lung epithelial cells generated from patient iPSCs. Cell Rep. 2015, 12, 1385-1390. [CrossRef]

111. McCauley, K.B.; Hawkins, F.; Serra, M.; Thomas, D.C.; Jacob, A.; Kotton, D.N. Efficient derivation of functional human airway epithelium from pluripotent stem cells via temporal regulation of Wnt signaling. Cell Stem Cell 2017, 20, 844-857. [CrossRef] [PubMed]

112. Dye, B.R.; Hill, D.R.; Ferguson, M.A.; Tsai, Y.H.; Nagy, M.S.; Dyal, R.; Wells, J.M.; Mayhew, C.N.; Nattiv, R.; Klein, O.D.; et al. In vitro generation of human pluripotent stem cell derived lung organoids. Elife 2015, 4, e05098. [CrossRef]

113. Miller, A.J.; Dye, B.R.; Ferrer-Torres, D.; Hill, D.R.; Overeem, A.W.; Shea, L.D.; Spence, J.R. Generation of lung organoids from human pluripotent stem cells in vitro. Nat. Protoc. 2019, 14, 518-540. [CrossRef]

114. Crane, A.M.; Kramer, P.; Bui, J.H.; Chung, W.J.; Li, X.S.; Gonzalez-Garay, M.L.; Hawkins, F.; Liao, W.; Mora, D.; Choi, S.; et al. Targeted correction and restored function of the CFTR gene in cystic fibrosis induced pluripotent stem cells. Stem Cell Rep. 2015, 4, 569-577. [CrossRef]

115. Berical, A.; Lee, R.E.; Lu, J.; Beermann, M.L.; LeSeur, J.A.; Mithal, A.; Thomas, D.; Ranallo, N.; Peasley, M.; Stuffer, A.; et al. A multimodal iPSC platform for cystic fibrosis drug testing. bioRxiv 2021. [CrossRef]

116. Jiang, J.X.; Wellhauser, L.; Laselva, O.; Utkina, I.; Bozoky, Z.; Gunawardena, T.; Ngan, Z.; Xia, S.; Eckford, P.D.W.; Ratjen, F.; et al. A new platform for high-throughput therapy testing on iPSC-derived, immature airway from Cystic Fibrosis Patients. bioRxiv 2021.

117. Ngan, S.Y.; Quach, H.; Dierolf, J.; Laselva, O.; Lee, J.-A.; Huang, E.; Mangos, M.; Xia, S.; Wong, A.P. Modeling lung cell development using human pluripotent stem cells. bioRxiv 2021. [CrossRef]

118. Hawkins, F.J.; Suzuki, S.; Beermann, M.L.; Barilla, C.; Wang, R.; Villacorta-Martin, C.; Berical, A.; Jean, J.C.; Le Suer, J.; Matte, T.; et al. Derivation of airway basal stem cells from human pluripotent stem cells. Cell Stem Cell 2021, 28, 79-95. [CrossRef]

119. Berkers, G.; van Mourik, P.; Vonk, A.M.; Kruisselbrink, E.; Dekkers, J.F.; de Winter-de Groot, K.M.; Arets, H.G.M.; Marck-van der Wilt, R.E.P.; Dijkema, J.S.; Vanderschuren, M.M.; et al. Rectal organoids enable personalized treatment of cystic fibrosis. Cell Rep. 2019, 26, 1701-1708. [CrossRef]

120. Konishi, S.; Gotoh, S.; Tateishi, K.; Yamamoto, Y.; Korogi, Y.; Nagasaki, T.; Matsumoto, H.; Muro, S.; Hirai, T.; Ito, I.; et al. Directed induction of functional multi-ciliated cells in proximal airway epithelial spheroids from human pluripotent stem cells. Stem Cell Rep. 2016, 6, 18-25. [CrossRef] [PubMed]

121. Chen, Y.W.; Huang, S.X.; de Carvalho, A.; Ho, S.H.; Islam, M.N.; Volpi, S.; Notarangelo, L.D.; Ciancanelli, M.; Casanova, J.L.; Bhattacharya, J.; et al. A three-dimensional model of human lung development and disease from pluripotent stem cells. Nat. Cell Biol. 2017, 19, 542-549. [CrossRef] [PubMed]

122. Zhou, J.; Li, C.; Sachs, N.; Chiu, M.C.; Wong, B.H.; Chu, H.; Poon, V.K.; Wang, D.; Zhao, X.; Wen, L.; et al. Differentiated human airway organoids to assess infectivity of emerging influenza virus. Proc. Natl. Acad. Sci. USA 2018, 115, 6822-6827. [CrossRef] [PubMed] 